\title{
Pellavan siemenen laadun kehittäminen
}

Hanna-Riitta Kymäläinen ${ }^{1)}$ ja Anna-Maija Sjöberg ${ }^{1)}$

${ }^{1)}$ Helsingin yliopisto, Agroteknologian laitos, PL 28 (Koetilantie 3), 00014 Helsingin yliopisto

hanna-riitta.kymalainen@helsinki.fi

\section{Tiivistelmä}

Suomalaiset öljypellavayritykset ovat kiinnostuneita tuotteidensa laadun kehittämisestä. Helsingin yliopiston Agroteknologian laitoksessa luodun Laaturenkaan avulla on tutkittu ja arvioitu erilaisia laatuun vaikuttavia ominaisuuksia. Öljypellavan laadun kehittäminen on osana vuonna 2005 päättynyttä Agrokuituverkosto-hanketta. Tähän hankkeeseen osallistuivat Palmenia, Helsingin yliopiston Agroteknologian laitos sekä öljypellavayritykset.

Osana Agrokuituverkoston toimintaa on vuosina 2004-2005 Helsingin yliopiston Agroteknologian laitoksen toteuttama kadmiumselvitys. Selvitystä varten yritykset toimittivat öljypellavanäytteitä kadmiumanalyyseihin. Mitattuja arvoja verrattiin kansainvälisiin pitoisuuksiin ja hyväksyttävästä päiväsaannista esitettiin arviot. Tulokseksi saadut kadmiumpitoisuudet ovat samaa tasoa kuin kansainvälisissä tutkimuksissa. Normaalilla suomalaisella ruokavaliolla pellavansiementä saa kadmiumin suhteen syödä turvallisesti suositellun määrän $24 \mathrm{~g}-30 \mathrm{~g}$. Suomalaisen pellavan kadmiumpitoisuus ei siis aiheuta normaaleilla päiväannoksilla (esim. $24 \mathrm{~g}$ pellavaa päivässä) erityistä riskiä, kun asiaa tarkastellaan nykyisen WHO:n asettaman PTDI-arvon (Provisional Tolerable Daily Intake) kannalta. Runsaskadmiumisen ruokavalion lisänä em. päiväannokset voivat olla liian suuret, jos käytetään korkean kadmiumpitoisuuden omaavaa pellavaa. Jos pellavansiementä käytetään päivässä alle $24 \mathrm{~g}$ määrä, riskit vähenevät vastaavasti. Poikkeuksena ovat ne henkilöt, joilla on muitakin riskitekijöitä kadmiumin saannin suhteen, esim. saastunut asuinalue, tupakointi tai alentunut sietokyky. Tällöin on kiinnitettävä enemmän huomiota kadmiumin kokonaissaantiin ja saantiin myös pellavan siemenen osalta. Osasta pellavan siemeniä mitattiin myös rasvahappokoostumus ja muut laatuominaisuudet. Lajikkeiden välillä oli eroja erityisesti proteiinipitoisuuksissa, $\alpha$-linoleenihappopitoisuuksissa sekä fenolisten yhdisteiden määrässä.

Asiasanat: Öljypellava, siemen, rouhe, laatu, kadmium, koostumus, proteiinit, rasvahapot, ravintokuitu 


\section{Johdanto}

Öljypellavalla (Linum usitatissimum L.) on useita myönteisiä terveysvaikutteisia ominaisuuksia, kuten hyvä rasvahappokoostumus. Siemen sisältää myös proteiinia ja ravintokuitua. Öljypellavan siemenellä on teollista potentiaalia funktionaalisena elintarvikkeena tai sen raaka-aineena (Oomah 2001). Suomessa toimii useita pellavaa tuottavia ja jalostavia yrityksiä. Ne ovat kiinnostuneita tuotteidensa laadun kehittämisestä. Helsingin yliopiston Agroteknologian laitoksessa luodun Laaturenkaan avulla on tutkittu ja arvioitu erilaisia laatuun vaikuttavia ominaisuuksia. Tähän toimintaan osallistuivat Palmenia, Helsingin yliopiston Agroteknologian laitos sekä öljypellayritykset. Öljypellavan laadun kehittäminen on osana vuonna 2005 päättynyttä Agrokuituverkosto-hanketta. Pellava sisältää myönteisten tekijöiden lisäksi myös haitallisia komponentteja, joista eräs on kadmium. Pellava ottaa maasta herkästi ja myös alhaisina pitoisuuksina kadmiumia $\mathrm{Cd}^{2+}$-ionin muodossa (Chakravarty ja Srivastava 1997). Kadmium on raskasmetalli, joka kertyy ihmisen kehoon ja aiheuttaa erilaisia lääketieteellisiä haittoja. Ruoka on merkittävin kadmiumin lähde muille kuin tupakoiville (WHO 2000) ja teollisuuden saastuttamalla alueella eläville henkilöille (Heinzow ym. 1991). Osana Agrokuituverkoston toimintaa vuosina 2004-2005 toteutettiin kadmiumselvitys, jonka tavoitteena oli selvittää suomalaisen pellavansiemenen kadmiumpitoisuutta ja arvioida hyväksyttävää päiväsaantia. Lisäksi tutkittiin talousviljelykokeessa pellavan siemenien kemiallinen koostumus.

\section{Aineisto ja menetelmät}

Helsingin yliopiston Siuntion koeasemalta kerättiin vuosien 2002-2004 sadosta 24 siemennäytettä ja kaupallisilta viljelmiltä vuosien 2002-2003 sadosta 61 näytettä Etelä-Suomesta ja Pohjanmaalta. Lisäksi tutkittiin 15 öljypellavarouhenäytettä, jotka oli tuotettu kaupallisista siemenistä. Näytteiden Cd-pitoisuudet analysoitiin Vantaan kaupungin Elintarvike- ja Ympäristölaboratoriossa atomiabsorptioon perustuvalla standardimenetelmällä NMKL 161 (1998). Cadmiumpitoisuuksien elueellisia eroja selvitettiin SPSS-ohjelman varianssianalyysillä (One-way ANOVA, Tukeyn post hoc -testi). Koetilalta vuoden 2003 sadosta kerättyjen pellavansiemenien koostumus määritettiin MTT:ssä.

\section{Tulokset ja tulosten tarkastelu Öljypellavan kadmiumpitoisuus}

Öljypellavan kadmiumpitoisuus vaihteli 0,27 ja $1,3 \mathrm{mg} \mathrm{kg}^{-1}$ (dw) välillä, keskiarvo oli $0,62 \mathrm{mg} \mathrm{kg}^{-1}$. Pellavarouheen kadmiumpitoisuus oli välillä 0,47 ja $1,5 \mathrm{mg} \mathrm{kg}^{-1}$ (dw), keskiarvo oli $0,85 \mathrm{mg} \mathrm{kg}^{-1}$. Siuntion koetilalta viljellyissä näytteissä oli korkeimmat*** Cd-pitoisuudet verrattuna muihin Etelä-Suomesta ja Pohjanmaalta kerättyihin näytteisiin. Tulokset ovat samaa tasoa kuin kansainvälisissä tutkimuksissa. Myös niissä pellavan kadmiumpitoisuus on vaihdellut suuresti, esimerkiksi Marquardin ym. (1990) tutkimuksessa 0,10 ja $1.70 \mathrm{mg} \mathrm{kg}^{-1}(\mathrm{dw})$ välillä. Pellavarouheen kadmiumpitoisuus oli keskimäärin $56 \%$ (vaihteluväli 12$138 \%$ ) korkeampi kuin vastaavien siementen pitoisuus. Rouheen keskimääräinen pitoisuus oli samalla tasolla kuin Siuntiosta kerättyjen kokonaisten siementen pitoisuus.

\section{Arvioitu kadmiumin päiväsaanti}

Tutkimusten mukaan $24 \mathrm{~g}$ päivittäinen pellavan syöntimäärä on turvallinen (Tarpila ym. 2004) ja kanadalaisten mukaan $30 \mathrm{~g}$ on ihanteellinen määrä rasvahappojen funktionaalisten komponenttien hyödyntämiseksi (Morris 2003). Näitä syöntimääriä käytettiin arvioitaessa kadmiumin saantia pellavasta. Jos kaikki henkilön saama kadmium tulisi pellavasta, $70 \mathrm{~kg}$ painoinen henkilö voisi syödä suomalaista pellavansiementä 55-263 g tai rouhetta 47-151 g riippuen pellavan Cd-pitoisuudesta. Koska pellavaa käytetään kuitenkin vain pienehköjä määriä päivittäin, saantimäärät laskettiin tästä näkökulmasta. Kadmiumin enimmäispäiväsaanti ruoasta on Tahvosen (1995) mukaan $11 \mu \mathrm{g}$. Jos saamme kadmiumia lisäksi pellavasta, tämä pellavasta saatava kadmiummäärä voisi olla 30-60 $\mu \mathrm{g}$, jotta WHO/FAOn (1993) asettama PTDI (Provosional Tolerable Daily Intake) -arvo $\left(70 \mu \mathrm{g} \mathrm{d}^{-1}\right)$ ei ylittyisi . Henkilön paino vaikuttaa kuitenkin merkittävästi siihen, miten paljon kadmiumia pellavasta voisi saada ylittämättä WHO:n asettamaa PTDIarvoa. Jos henkilön paino on yli $70 \mathrm{~kg}$, sallittu syöntimäärä on korkeampi kuin edellä esitetyt 24-30 g suositusmäärät. Jos henkilön paino on kuitenkin suhteellisen alhainen (50 kg tai sen alle) ja lisäksi ravinnosta tai ympäristöstä saadaan paljon kadmiumia, raja on melko lähellä jos käytetään pellavaa, jolla on korkea kadmiumpitoisuus (Kymäläinen ja Sjöberg 2005). 


\section{Pellavan muut laatuominaisuudet}

Kolmen tutkitun lajikkeen, Laserin, Helmen ja Bor-linjan koostumus oli taulukon 1 mukainen. Tuloksia verrataan tässä Morrisin (2003) esittämiin arviohin, mutta on otettava huomioon, että lajikkeiden väliset laatuominaisuudet vaihtelevat suuresti kansainvälisissä tutkimuksissa. Eräs kiinnostava ero lajikkeiden välillä oli $\alpha$-linoleenihappopitoisuuksissa (vertailuarvo 57,0 \%; Morris 2003). Linolihappopitoisuus oli samaa tasoa kuin vertailuarvo $16,0 \%$. Tyydyttyneiden rasvahappojen määrä oli hieman alempi kuin kanadalainen vertailuarvo 9,0 ja tyydyttymättömien rasvahappojen määrä hieman korkeampi kuin vertailuarvot 18,0\% (kertatyydyttymättömät) ja 72,8 \% (monityydyttymättömät). Proteiini- ja kokonaisravintokuitupitoisuudet olivat hieman vertailuarvoa 22,3\% (proteiinit) ja 28,0 (kokonaisravintokuitu) alhaisemmat. Fenolisten yhdisteiden pitoisuus oli korkein yleisesti kasvatetussa Helmi-lajikkeessa. Fenolisiin yhdisteisiin kuuluvat mm. lignaanit.

Taulukko 1. Siuntion koetilalla vuoden 2003 talousviljelykokeessa kasvatettujen pellavalajikkeiden siemenen koostumus kahden mittaustuloksen keskiarvona.

\begin{tabular}{|c|c|c|c|c|}
\hline \multirow{2}{*}{\multicolumn{2}{|c|}{ Koostumusanalyysi }} & \multicolumn{3}{|c|}{ Pellavalajike } \\
\hline & & Helmi & Laser & Bor-linja \\
\hline \multicolumn{2}{|c|}{ Proteiini $(\%)$} & 19,0 & 16,1 & 19,0 \\
\hline \multicolumn{2}{|c|}{ Kokonaisravintokuitu (\%) } & 25,5 & 24,6 & 25,5 \\
\hline \multicolumn{2}{|c|}{ Kokonaispentosaanit (\%) } & 6,6 & 7,7 & 6,6 \\
\hline \multicolumn{2}{|c|}{ Fenoliset yhdisteet $(\mathrm{mg} / \mathrm{kg})$} & 4736 & 3236 & 4637 \\
\hline \multirow{11}{*}{$\begin{array}{l}\text { Rasva- } \\
\text { hapot (\%) }\end{array}$} & C16:0 (palmitiinihappo) & 4,3 & 4,1 & 4,1 \\
\hline & C18:0 (steariinihappo) & 2,7 & 3,1 & 3,0 \\
\hline & C18:1 (vakseenihappo) & 0,5 & 0,4 & 0,5 \\
\hline & C18:1 (öljyhappo) & 19,0 & 17,0 & 20,0 \\
\hline & C18:2 (linolihappo) & 16,1 & 15,6 & 17,4 \\
\hline & C18:3 ( $\gamma$-linoleenihappo) & 0,1 & 0,1 & 0,1 \\
\hline & C18:3 ( $\alpha$-linoleenihappo) & 57,3 & 59,6 & 54,9 \\
\hline & C20:1 & 0,1 & 0,0 & 0,0 \\
\hline & tyydyttyneet rasvahapot & 7,0 & 7,2 & 7,1 \\
\hline & kertatyydyttymättömät rasvahapot & 19,5 & 17,4 & 20,5 \\
\hline & monityydyttymättömät rasvahapot & 73,5 & 75,3 & 72,4 \\
\hline
\end{tabular}

\section{Johtopäätökset}

Suomalaisen pellavan kadmiumpitoisuus oli samaa tasoa kuin kansainvälisissä tutkimuksissa. Normaalilla suomalaisella ruokavaliolla pellavansiementä saa kadmiumin suhteen syödä turvallisesti suositellun määrän $24 \mathrm{~g}$ - $30 \mathrm{~g}$. Jos henkilön paino on alhainen (alle $50 \mathrm{~kg}$ ) ja ruokavalio sekä pellava runsaskadmiumista, em. päiväannoksia voi olla syytä pienentää. Eri lajikkeiden rasvahappo- ja muu koostumus erosi hieman toisistaan, mutta erojen tarkempaan selvittämiseen tarvittaisiin laajempaa tutkimusta.

\section{Kiitokset}

Tutkimuksen rahoitti EMOTR/ALMA-ohjelmaan kuuluva Agrokuituverkosto-hanke. Kiitämme Aija Kortesmaata Palmeniasta, Eero Lammista Helsingin yliopiston Suitian koetilalta sekä Helsingin yliopiston Flax Teamia yhteistyöstä sekä suomalaisia öljypellavayrityksiä (Elixi Oil Oy, Oy Linseed Protein Finland Ltd, Neomed Oy ja Sini-Pellava Oy) yhteistyöstä ja näytteistä.

\section{Kirjallisuus}

Chakravarty, B. \& Srivastava, S. 1997. Effect of cadmium and zinc interaction on metal uptake and regeneration of tolerant plants in linseed. Agriculture, Ecosystems and Environment 61:45-50.

Heinzow, B., Jessen, H., Mohr, S. \& Riemer, D. 1991. Heavy metals in the general population: trend evaluation and interrelation with trace elements. Julkaisussa: Aitio, A., Aro, A., Järvisalo, J., Vainio, H., toim. Trace elements in health and disease. Iso-Britannia: The Royal Society of Chemistry. s. 75.

Kymäläinen, H.-R \& Sjöberg, A.-M. 2005. Cadmium content of linseed and estimated consumer intake. Submitted manuscript.

Marquard R, Boehm H, Friedt W. 1990. Untersuchungen über Cadmiumgehalte in Leinsaat (Linum usitatissimum 
L.). Fat Science and Technology 92:468-472.

Morris, D.H. 2003. Flax, a health and nutrition primer. Winnipeg: Flax Council of Canada. 112 p.

NMKL 161. 1998. Metals. Determination by atomic absorption spectrophotometry after wet digestion in a microwave oven. Norway: National Veterinary Institute.

Oomah, B.D. 2001. Flaxseed as a functional food source. Journal of Science of Food and Agriculture 81:889-894.

Tahvonen, R. 1995. Contents of lead and cadmium in foods in Finland, Academic dissertation. University of Turku, Department of Biochemistry and Food Chemistry.

Tarpila, S., Tarpila, A., Gröhn, P., Silvennoinen, T. \& Lindberg. L. 2004. Efficacy of ground flaxseed on constipation in patients with irritable bowel syndrome. Current Topics in Nutraceutical Research 2:119-125.

WHO/FAO 1993. Toxicological evaluation of certain food additives and contaminants. WHO Technical Reports Series No. 837. In: The 41st Meeting of the Joint FAO/WHO Expert committee on Food Additives. 